International Journal of Current Microbiology and Applied Sciences

ISSN: 2319-7706 Volume 10 Number 02 (2021)

Journal homepage: http://www.ijcmas.com

\title{
Profile of Farmers Regarding Knowledge and Use of Biomix
}

\author{
G. S. Borase*, M. V. Kulkarni and S. P. Dhoke \\ Department of Extension Education College of Agriculture, Parbhani \\ Vasantrao Naik Marathwada Krishi Vidyapeeth, Parbhani (M.S.) India \\ *Corresponding author
}

Keywords

Biomix

Knowledge, Use profile of farmers

Article Info

Accepted:

17 January 2021

Available Online:

10 February 2021

\section{A B S T R A C T}

The present study explored profile characteristics of farmers about knowledge and use of Biomix. This study was purposively conducted in Vasmat and Aundha tahsils of Hingoli district on the basis of maximum number of Biomix use from this district of Marathwada. 120 farmers were selected from six selected villages by using Purposive simple random sampling method. For this study the variables taken namely Age, Education, Land holding, Occupation, Annual income, Socio-economic status, and source of information, Extension contact, social participation, Risk orientation, and Market orientation. The variables namely education, land holding, occupation, extension contact, social participation had positive and highly significant relationship with their knowledge level. Other characteristics namely age is positively non significant and annual income is negatively non significant with the knowledge of farmers. While land socio-economic status, sources of information, risk orientation, market orientation had positive and significant relationship with knowledge.

\section{Introduction}

Biopesticides are living organisms which can intervene the life cycle of insect pests in such a way that the crop damage is minimized. The agents employed as biopesticides, include parasites, predators and disease-causing fungi, bacteria and viruses, which are the natural enemies of pests. Further, they complement and supplement other methods of pest control. Utilization of naturally occurring parasites, predators and pathogens for pest control is a classical biological control. On the other hand, these bio agents can be conserved, 
preserved and multiplied under Laboratory condition for field release. Once these bioagents are introduced in the field to build their population considerably, they are capable of bringing down the targeted pest population below economic threshold level (ETL). However, the crux lies in their mass production and application at the appropriate time (TNAU Agri Portal).

It is a known fact that the bioagents are playing important role in plant disease management, pest management and boosting the plant growth. Department of pathology introduced biocontrol in the Marathwada region and developed an experimental product for management of citrus decline during 2005. Named it as "Biomix" (A mixture of Trichoderma spp.and P. fluoroscens). This product has a great impact on farmers. In the year 2010, the farmers from Girgaon and Kurunda, the turmeric growing part of Hingoli district reached department of Plant Pathology, College of Agriculture, VNMKV, Parbhani for the problem of rhizome rot and white grub, their expenditure on management of this disease and pest was more than 50,000/per acre and they asked his help in solving the problem. Based on the performance, literature and problems in turmeric, an improved Biomix was formulated by adding some bio fungicides, biopesticides and growth promoting bioagents. This product solved the all major problems in turmeric.

They said that Biomix has not only solved the problems of soft rot and white grub in turmeric but also improved the quality and yield of turmeric. Some farmers told that due to use of Biomix, turmeric has fetched the highest market value. The Biomix is also used in different crops like Ginger, Tomato. Mango, Groundnut and Citrus. Pomegranate, Watermelon, Papaya, different vegetable and legume crops like Tur and Soybean. The results of the use of Biomix are very promising and it is found effective against different diseases, pests and promoted the growth of crops. This product has crossed the borders of Maharashtra and it is also used in Gujarat and Karnataka now (Department of Plant Pathology, College of Agriculture, Parbhani VNMKV, Parbhani).

The present study was carried out in Marathwada region of Maharashtra State during the year 2019-20. The present investigation was carried out in Marathwada region for the study one district is selected purposively, i.e. Hingoli. In Hingoli district of two talukas selected purposively i.e. Vasmat and Hingoli. In selected talukas six villages were purposively selected, thus total ten villages were selected for the present investigation. From each selected village, fifteen (15) farmers were selected purposively. Hence, a total of 120 respondents were selected for the study. The Ex-post facto research design was used in the present study, statistically analyzed by using statistical techniques like frequency, percentage. For the study, the interview schedule based on the objectives of the study was prepared for collecting data from the respondents. The findings regarding the profile of farmers about knowledge and use of biomix.

The main objectives of this study include to study the Profile of farmers about knowledge and use of biomix 
Table.1 Profile characteristics of the respondents

\begin{tabular}{|c|c|c|c|}
\hline \multirow[t]{2}{*}{ Sr. No. } & & \multicolumn{2}{|c|}{ Respondents $(\mathrm{n}=120)$} \\
\hline & & Number & Percentage \\
\hline \multirow[t]{4}{*}{1} & \multicolumn{3}{|l|}{ Age } \\
\hline & Young (up to 31 years) & 32 & 26.66 \\
\hline & Middle age (32 to 41 years) & 70 & 58.34 \\
\hline & Old (42 and above) & 18 & 15 \\
\hline \multirow[t]{9}{*}{2} & \multicolumn{3}{|l|}{ Education } \\
\hline & Illiterate & 12 & 10 \\
\hline & Literate (Can only read and write) & 4 & 3.33 \\
\hline & Primary ( $1^{\text {st }}$ to $4^{\text {th }}$ Std. $)$ & 14 & 11.66 \\
\hline & Primary $\left(5^{\text {th }}\right.$ to $7^{\text {th }}$ Std. $)$ & 27 & 22.5 \\
\hline & Secondary $\left(8^{\text {th }}\right.$ to $10^{\text {th }}$ Std. $)$ & 16 & 13.33 \\
\hline & Higher secondary education $\left(11^{\text {th }} \& 12^{\text {th }}\right.$ Std. $)$ & 34 & 28.35 \\
\hline & Graduate (Above $12^{\text {th }}$ Std.) & 9 & 7.5 \\
\hline & Post Graduate & 4 & 3.33 \\
\hline \multirow[t]{7}{*}{3} & Land holding & & \\
\hline & Labour & 17 & 14.16 \\
\hline & Caste occupation & 6 & 5.02 \\
\hline & Business & 7 & 5.83 \\
\hline & Independent profession & 9 & 7.50 \\
\hline & Cultivation & 68 & 56.66 \\
\hline & Service & 13 & 10.83 \\
\hline \multirow[t]{6}{*}{4} & \multicolumn{3}{|l|}{ Land holding } \\
\hline & Marginal ( Up to $1.00 \mathrm{ha}$ ) & 22 & 18.33 \\
\hline & Small (1.01 to $2.00 \mathrm{ha})$ & 41 & 34.16 \\
\hline & Small medium ( 2.01 to $4.00 \mathrm{ha}$ ) & 32 & 26.66 \\
\hline & Medium (4.01 to 10.00 ha ) & 23 & 19.16 \\
\hline & Large ( 10.01 and above) & 2 & 1.69 \\
\hline \multirow[t]{4}{*}{5} & \multicolumn{3}{|l|}{ Annual Income } \\
\hline & Low (Above Rs. 99961) & 28 & 23.33 \\
\hline & Medium (Rs. 99962 to Rs.240637) & 74 & 61.67 \\
\hline & High (Rs.240638 and above ) & 18 & 15.00 \\
\hline \multirow[t]{4}{*}{6} & Socio-Economic Status & & \\
\hline & Low ( up to 15$)$ & 21 & 17.50 \\
\hline & Medium ( 16 to 21 ) & 80 & 66.67 \\
\hline & High ( 22 and above) & 19 & 15.83 \\
\hline \multirow[t]{4}{*}{7} & \multicolumn{3}{|l|}{ Sources of information } \\
\hline & Low ( up to 12 ) & 25 & 20.83 \\
\hline & Medium ( 13 to 16 ) & 75 & 62.50 \\
\hline & High ( 17 and above ) & 20 & 16.67 \\
\hline \multirow[t]{4}{*}{8} & \multicolumn{3}{|l|}{ Extension contact } \\
\hline & Low (up to 3) & 24 & 20 \\
\hline & Medium (4 to 6 ) & 73 & 60.83 \\
\hline & High (7 and above) & 23 & 19.17 \\
\hline \multirow[t]{3}{*}{9} & \multicolumn{3}{|l|}{ Social participation } \\
\hline & Low ( up to 3 ) & 34 & 28.33 \\
\hline & Medium ( 4 to 5 ) & 63 & 52.51 \\
\hline
\end{tabular}




\begin{tabular}{|c|c|c|c|}
\hline & High (6 and above ) & 23 & 19.16 \\
\hline \multirow[t]{4}{*}{10} & \multicolumn{3}{|l|}{ Risk orientation } \\
\hline & Low ( up to 24 ) & 23 & 19.16 \\
\hline & Medium ( 25 to 27 ) & 78 & 65.01 \\
\hline & High ( 28 and above) & 19 & 15.83 \\
\hline \multirow[t]{4}{*}{11} & \multicolumn{3}{|l|}{ Market Orientation } \\
\hline & Low ( up to 24 ) & 26 & 21.67 \\
\hline & Medium ( 25 to 26 ) & 85 & 70.83 \\
\hline & High ( 27 and above) & 9 & 7.50 \\
\hline
\end{tabular}

In conclusion, most of the farmers were from middle age group, had educated up to higher secondary education level and belongs to small size land holding. Revealed that majority of farmers were engaged in farming, farmers categorized under medium level of annual income. majority belonged to medium level of socio-economic status, More than two third of the farmers uses medium sources of information. Most farmers have medium extension contact, majority of the farmers having medium social participation, that more than half farmers have medium level risk orientation and 70.00 per cent had medium level of market orientation.

\section{References}

Ahire, R.D., P.S. Kapse and Deshmukh, P.R. 2018. Socio-Economic and Psychological Determinants of Knowledge and Adoption of IPM Technology for Management of White Grub among the Farmers. Int.J.Curr.Microbiol.App.Sci. 7(09): 1201-1206.

Akkamahadevi Naik, M. Sreenivasulu, I.
Sreenivasa Rao and Mahesh Lankati. 2018. A Study on Knowledge Level of Farmers on Organic Red Gram Cultivation Practices in Dryland Areas of Karnataka, India. Int.J.Curr.Microbiol.App.Sci. $\quad$ 7(03): 435-440.

Bedre, V. S. (2009): Knowledge and adoption of recommended package of practices by okra growers, M.Sc. (Agri.) Thesis, MAU, Parbhani (M.S.).

Jakkawad, S.D., N.R. Patangeand S.B. Kadam (2019): Extent of adoption of practices by cotton growers, ISSN 0974-8431, 246-250.

Lad, A.S. (2013) Knowledge and adoption of recommended package of practices of green gram. M.Sc. (Agri.) Thesis, VNMKV, Parbhani (M.S.).

Sawale, S. V. (2011) Knowledge and adoption of post-harvest technology by the pomegranate growers M.Sc. (Agri.) Thesis submitted to MAU, Parbhani.

Shete, D. S. (2014) Knowledge and adoption of drip irrigation for sugarcane. M.Sc. (Agri.) Thesis, VNMKV, Parbhani.

\section{How to cite this article:}

Borase, G.S., M.V. Kulkarni and Dhoke, S.P. 2021. Profile of Farmers Regarding Knowledge and Use of Biomix. Int.J.Curr.Microbiol.App.Sci. 10(02): 3259-3262.

doi: https://doi.org/10.20546/ijcmas.2021.1002.357 